\title{
PRODUCTION POTENTIAL AND WEED DYNAMICS IN MAIZE + LEGUMES INTERCROPPING SYSTEM
}

\author{
Q. Naher*, S.M.R. Karim ${ }^{1}$, M. Begum ${ }^{1}$ and M.A. Hossain* \\ *On- Farm Research Division, Bangladesh Agricultural Research Institute, Joydebpur, Gazipur 1701, Bangladesh \\ ${ }^{1}$ Professor, Agronomy Division, Bangladesh Agricultural University, Mymensingh \\ Corresponding email: ofrdjoy@yahoo.com
}

(Received: 03 September, 2020, Accepted: 26 September, 2020)

Keywords: Maize, legume, intercropping, productivity, competitive ability

\begin{abstract}
The experiment was carried out at the Bangladesh Agricultural Research Institute, Gazipur during summer season of 2012 to identify suitable legume crops for growing with maize in a maize + legume intercropping system for better weed suppression, system productivity and economic benefits in kharif season. There were 17 treatments, viz. $\mathrm{T}_{1}=$ Sole maize (no weeding), $T_{2}=$ Maize + Mungbean (no weeding), $T_{3}=$ Maize + Mungbean (weeding at $20 \mathrm{DAE}$ ), $\mathrm{T}_{4}=$ Maize + Mungbean (weeding at $40 \mathrm{DAE}$ ), $\mathrm{T}_{5}=$ Maize + Mungbean (weeding at 20 and $40 \mathrm{DAE}$ ), $\mathrm{T}_{6}=$ Maize + Soybean (no weeding), $\mathrm{T}_{7}=$ Maize + Soybean (weeding at $20 \mathrm{DAE}$ ), $\mathrm{T}_{8}=$ Maize + Soybean (weeding at $\left.40 \mathrm{DAE}\right), \mathrm{T}_{9}=$ Maize + Soybean (weeding at 20 and $40 \mathrm{DAE}), \mathrm{T}_{10}=$ Maize + Blackgram (no weeding), $\mathrm{T}_{11}=$ Maize + Blackgram (weeding at $20 \mathrm{DAE}$ ), $\mathrm{T}_{12}=$ Maize + Blackgram (weeding at 40 $\mathrm{DAE}$ ), $\mathrm{T}_{13}=$ Maize + Blackgram (weeding at 20 and $\left.40 \mathrm{DAE}\right) \mathrm{T}_{14}=$ Sole maize (weed free), $\mathrm{T}_{15=}$ Sole Mungbean (weed free), $\mathrm{T}_{16}=$ Sole Soybean (weed free) and $\mathrm{T}_{17}=$ Sole Blackgram (weed free) were studied. Intercropping systems significantly reduced the weed population and weed dry biomass in comparison to sole cropping of maize under unweeded situation. Among the three different intercropping systems, maize + mungbean with two hand weedings produced the lowest weed dry weight (184.30 g at $20 \mathrm{DAE}$ and $14.07 \mathrm{~g}$ at $40 \mathrm{DAE})$ and the highest weed control efficiency (87\% at $40 \mathrm{DAE})$ followed by maize + soybean and maize + blackgram intercropping systems. The highest grain yield was obtained from weed free sole maize $\left(8.05 \mathrm{t} \mathrm{ha}^{-1}\right)$ than unweeded sole maize $\left(6.48 \mathrm{t} \mathrm{ha}^{-1}\right)$ treatment. Among all intercropping, maize + mungbean along with two hand weedings gave the highest yield (maize: $7.18 \mathrm{t} \mathrm{ha}^{-1} ; 572.6 \mathrm{~kg} \mathrm{ha}^{-1}$ mungbean), resource complementarity and profitability $\left(\mathrm{MEY}=10.62 \mathrm{t} \mathrm{ha}^{-1}, \mathrm{LER}=1.81\right.$ and $\mathrm{BCR}=2.47$ ). From the study it was concluded that maize + mungbean with two hand weedings at 20 and 40 DAE would be the best in reducing weed growth, producing maximum yield and getting net return in intercropping systems during kharif season.
\end{abstract}

\section{Introduction}

Maize (Zea mays L.) is one of the most versatile emerging crop having wider adaptability under varied agro-climatic conditions. Globally, maize is known as queen of cereals because it has the highest genetic yield potential among the cereals. It is a source of carbohydrate and used for both human consumption and animal feed worldwide due to its high feeding value (Undie et al., 2012). Wide range of weed flora invades maize crop and causes yield losses ranging from 34 to $67 \%$ and sometimes even more (Kumar and Thakur, 2005).

Weed management is, therefore, very important aspect to augment maize production. The wider row spacing in maize can be used to grow legumes which not only will act as a smoother crop but will give additional yield. Mungbean, soybean and blackgram as a potential kharif legumes of Bangladesh can be 
successfully intercropped with maize provided effective weeds control. Kharif maize suffers from severe weed competition and depending upon the intensity, nature, stages and duration of weed infestation, it causes yield losses from 28-100\% (Patel et al., 2006). Katsaruware and Manyanhaire (2009) concluded that maize-cowpea intercrops reduced weed biomass when compared to sole crops.

Intercropping is a practice of growing of two or more, generally, dissimilar crops simultaneously on the same piece of land with distinct row arrangement. With the rapid population increase, the demand for food has been increasing while land availability has been declining. Thus, the only way to increase agricultural production is to increase yield per unit area (Odedina et al., 2014). Legumes in maize based cropping systems are considered to be better alternatives for securing nitrogen economy and increasing yield of maize besides bonus yield, greater productivity per unit time and space and higher net returns of intercropping system over monoculture. This practice is an attractive strategy to smallholder farmers for increasing productivity, utilization of land and labour though intensification of land uses (Seran and Brintha, 2010). It can suppress the weed growth more than the sole crops (Baumann et al., 2000).

Weed management is commonly very labor intensive in small-holder agriculture, often constrains the land area that can be farmed, and inadequate weed control is often a major constraint yield (Wortmann et al., 2009). Crop suppression of weeds is an important component of weed management. Weeds are commonly more suppressed by crop competition in intercropping compared to sole cropping (Getachew et al., 2007). Intercropping of short-duration crops like cowpea, blackgram, greengram or sesbania between maize rows has been found quite effective in weed suppression. Since maize is grown in wide spaced rows, the short duration varieties of pulses and oilseeds can be intercropped with it successfully. Intercrop efficiency with varying levels of weed management has not been well studied for the maize-bean intercrop. The objective of this study was, therefore, to evaluate weeding and legumes effect in maize-legume intercropping on weed suppression, and the agronomic and economic efficiency of intercropping.

\section{Materials and Methods}

The experiment was conducted at the On-farm research field of Bangladesh Agricultural Research Institute, Joydebpur, Gazipur during kharif season of 2012. The experiment site was located at Chhiata Series under Agro-Ecological Zone-28. Before opening the land, the soil samples were taken from the spots of the experimental area and analyzed from the Soil Science Division, BARI. The soil analysis showed that the soil of the experimental field was loam in texture and low in organic matter $(1.16 \%)$. The soil $\mathrm{pH}$ is 7.2 and contained very low amount of total nitrogen $(0.061 \%)$, phosphorus $(3 \mu \mathrm{g} / \mathrm{g})$, sulphur $(0.6 \mu \mathrm{g} / \mathrm{g})$, zinc $(3.54 \mu \mathrm{g} / \mathrm{g})$, boron $(0.44 \mu \mathrm{g} / \mathrm{g})$ and potassium $(0.13 \mathrm{meq} . / 100 \mathrm{~g}$ soil $)$. During the period of experimentation the maximum and minimum temperature ranged from $27.1^{\circ} \mathrm{C}$ to $35.5^{\circ} \mathrm{C}$ and $21.4^{\circ} \mathrm{C}$ to $25.4^{\circ} \mathrm{C}$, respectively. Crops received total 201.4 and $240.1 \mathrm{~mm}$ rainfall distributed during Marchto July in 2012. There were 17 treatments viz., $\mathrm{T}_{1}=$ Sole maize (no weeding), $\mathrm{T}_{2}=$ Maize + Mungbean (no weeding), $\mathrm{T}_{3}=$ Maize + Mungbean (weeding at $20 \mathrm{DAE}$ ), $\mathrm{T}_{4}=$ Maize + Mungbean (weeding at $40 \mathrm{DAE}$ ), $\mathrm{T}_{5}=$ Maize + Mungbean (weeding at 20 and $40 \mathrm{DAE}$ ), $\mathrm{T}_{6}=$ Maize + Soybean (no weeding), $\mathrm{T}_{7}=$ Maize + Soybean (weeding at $\left.20 \mathrm{DAE}\right), \mathrm{T}_{8}=$ Maize + Soybean (weeding at $40 \mathrm{DAE}$ ), $\mathrm{T}_{9}=$ Maize + Soybean (weeding at 20 and $40 \mathrm{DAE}$ ), $\mathrm{T}_{10}=$ Maize + Blackgram (no weeding), $\mathrm{T}_{11}=$ Maize + Blackgram (weeding at $20 \mathrm{DAE}$ ), $\mathrm{T}_{12}=$ Maize + Blackgram (weeding at $\left.40 \mathrm{DAE}\right), \mathrm{T}_{13}=$ Maize + Blackgram (weeding at 20 and $40 \mathrm{DAE}$ ) $\mathrm{T}_{14}=$ Sole maize (weed free), $\mathrm{T}_{15}=$ Sole Mungbean (weed free) , $\mathrm{T}_{16}=$ Sole Soybean (weed free) and $\mathrm{T}_{17}=$ Sole Blackgram (weed free) were studied. Maize was sown in $75 \mathrm{~cm} \times 20 \mathrm{~cm}$ spacing both in sole and intercrop system. Mungbean, blackgram and soybean were sown in $30 \mathrm{~cm} \times 10 \mathrm{~cm}$ spacing in sole and intercrop situation. Planting arrangement in intercrop treatments, two rows of legumes accommodated between one row of maize. The trials were laid out in a randomized complete block design with three replications. The plot size was $5.0 \mathrm{~m} \times 4.5 \mathrm{~m}$. Maize variety BARI Hybrid Maize-7, mungbean variety BARI Mung-5, blackgram variety BARI Mash-3 and 
soybean variety BARI Soybean-5 were used as test crops. Fertilizer was applied for maize at the rate of 250-50-100-44-5-2 kg of N, P, K, S, Zn and B ha ${ }^{-1}$, respectively, from urea, triple super phosphate, muriate of potash, gypsum, zinc sulphate and boric acid, respectively. Half amount of $\mathrm{N}$ and full dose of other fertilizers were incorporated into the soil at the time of final land preparation. The remaining urea was top dressed in two equal installments at 8-10 leaf stage (30-35 DAS) and at tasseling stage (50-60 DAS) followed by irrigation. The fertilizer doses for grain legumes were 21-17-18 and 23-18-18 $\mathrm{kg}$ of $\mathrm{N}, \mathrm{P}, \mathrm{K} \mathrm{ha}{ }^{-1}$, respectively from Urea, TSP, MoP, respectively. In case of sole cropping of legumes, the entire fertilizers were applied. Sowing of both maize and legumes were done on 15 March 2012. Weed management was done as per treatment specification. Mature mungbean and blackgram were harvested at 65 DAE while soybean was harvested at 100 DAE. Maize was harvested at 120 DAE. Maize equivalent yield was computed using the formula of Bandyopadhaya (1984).

Maize equivalent yield $=\mathrm{Yim}+(\mathrm{Yil} \times \mathrm{Pl}) / \mathrm{Pm}$

Where,

Yil = Yield of intercrop legume $\left(\mathrm{t} \mathrm{ha}^{-1}\right)$

Yim = Yield of intercrop maize $\left(\mathrm{t} \mathrm{ha}^{-1}\right)$

$\mathrm{Pm}=$ Selling price of maize

$\mathrm{Pl} \quad=$ Selling price of legume

Weed control efficiency (WCE) was calculated using the following formula (Curz et al., 1986).

\section{Land equivalent ratio (LER)}

Land equivalent ratio (LER) was obtained according to Willey (1979) as follows:

$$
\text { LER }=\frac{\text { Yield of mazieasintercrop }}{\text { Yield of maizeassolecrop }}+\frac{\text { Yield of legum æasintercrop }}{\text { Yield of legum æassolecrop }}
$$

Competitive ratio (CR) (Willey and Rao, 1980)

Competitive ratio of maize: $(\mathrm{CRm}):\{(\mathrm{Yim} / \mathrm{Ysm}) / \mathrm{Yil} / \mathrm{Ysl})\} \times(\mathrm{Zl} / \mathrm{Zm})$

Competitive ratio of Legume: $(\mathrm{CRL}):\{(\mathrm{Yil} / \mathrm{Ysl}) /(\mathrm{Yim} / \mathrm{Ysm})\} \times(\mathrm{Zm} / \mathrm{Zl})$

Where,

Ysm = Yield of sole maize

Ysl = Yield of sole legume

Yim = Yield of intercrop maize

Yil $=$ Yield of intercrop legume

ZI = Proportion of legume in intercrop

$\mathrm{Zm}$ = Proportion of maize in intercrop

$$
\mathrm{WCE}=\frac{\mathrm{DWC}-\mathrm{DWT}}{\mathrm{DWC}} \times 100
$$

DWC $=$ Dry weight of weeds in the weedy check

DWT $=$ Dry weight of weeds in the weeding treatment

The collected data were statistically analyzed by using MSTAT programme and the means were adjudged by using LSD. Economic analysis was also done.

\section{Results and Discussion}

Weed density, weed dry weight and weed control efficiency (WCE) were affected by different intercropping system and weeding regime is presented in Table 1. Intercropping systems significantly reduced the weed population and weed dry biomass than sole cropping of maize under unweeded situation. Cynodon dactylon, Eleusine indica, Echinochloa crusgalli, Paspalum conjugatum, Cyperus rotundus L. and Physalis heterophyll were the common and dominant weeds in the maize field. In Kharif season, weed density, weed dry weight and weed control efficiency (WCE) were recorded at 20 DAE and 40 DAE. Maximum weed density (363.3 no. $\mathrm{m}^{-2}$ at $20 \mathrm{DAE}$ and $426 \mathrm{~m}^{-2}$ at $\left.40 \mathrm{DAE}\right)$ and 
weed dry weight (216.8g at 20 DAE and $284.4 \mathrm{~g}$ at $40 \mathrm{DAE}$ ) were recorded in unweeded monocultured maize crop. Among the three different intercropping systems, $\mathrm{T}_{5}$ (Maize + Mungbean with two hand weedings at 20 and $40 \mathrm{DAE})$ treatment provided the lowest weed density $\left(275.3 \mathrm{~m}^{-2}\right.$ at $20 \mathrm{DAE}$ and $53.33 \mathrm{~m}^{-2}$ at $\left.40 \mathrm{DAE}\right)$ and weed dry weight (184.3 $\mathrm{g}$ at $20 \mathrm{DAE}$ and $14.07 \mathrm{~g}$ at $\left.40 \mathrm{DAE}\right)$ and it was followed by maize + soybean and maize + blackgram (Table 1$)$.

Table 1 . Weed density, weed dry weight and weed control efficiency $(\%)$ in different maize + legumes intercropping systems during the Kharif season of 2012

\begin{tabular}{ccccccc}
\hline Treatments & \multicolumn{2}{c}{$\begin{array}{c}\text { Weed density } \\
\left(\mathbf{n o .} \mathbf{~ m}^{-2}\right)\end{array}$} & \multicolumn{2}{c}{$\begin{array}{c}\text { Weed dry weight } \\
\left(\mathbf{g ~ m}^{-2}\right)\end{array}$} & \multicolumn{2}{c}{ Weed control efficiency (\%) } \\
\cline { 2 - 7 } & $\mathbf{2 0 ~ D A E}$ & $\mathbf{4 0} \mathbf{~ D A E}$ & $\mathbf{2 0 ~ D A E}$ & $\mathbf{4 0 ~ D A E}$ & $\mathbf{2 0}$ DAE & 40 DAE \\
\hline $\mathrm{T}_{1}$ & 363.30 & 426.00 & 216.80 & 284.40 & - & - \\
$\mathrm{T}_{2}$ & 284.70 & 324.30 & 190.50 & 178.00 & 21.32 & 23.84 \\
$\mathrm{~T}_{3}$ & 283.00 & 113.00 & 189.10 & 25.61 & 21.82 & 73.40 \\
$\mathrm{~T}_{4}$ & 270.70 & 326.30 & 181.20 & 157.90 & 25.25 & 23.27 \\
$\mathrm{~T}_{5}$ & 275.30 & 53.33 & 184.30 & 14.07 & 24.05 & 87.53 \\
$\mathrm{~T}_{6}$ & 293.30 & 330.70 & 196.30 & 182.60 & 18.83 & 22.34 \\
$\mathrm{~T}_{7}$ & 286.00 & 85.67 & 192.20 & 35.17 & 21.12 & 79.82 \\
$\mathrm{~T}_{8}$ & 289.30 & 333.30 & 193.70 & 163.90 & 20.13 & 21.65 \\
$\mathrm{~T}_{9}$ & 291.00 & 62.00 & 194.80 & 17.50 & 19.55 & 85.46 \\
$\mathrm{~T}_{10}$ & 310.00 & 330.30 & 207.50 & 181.20 & 14.13 & 22.38 \\
$\mathrm{~T}_{11}$ & 280.70 & 64.00 & 187.80 & 17.67 & 22.42 & 84.96 \\
$\mathrm{~T}_{12}$ & 277.30 & 349.30 & 185.60 & 179.60 & 23.46 & 17.87 \\
$\mathrm{~T}_{13}$ & 290.30 & 99.33 & 190.30 & 38.50 & 19.82 & 76.71 \\
\hline $\mathrm{LSD}_{(0.05)}$ & 20.37 & 22.54 & 11.75 & 8.90 & 4.97 & 6.04 \\
$\mathrm{CV}_{(\%)}$ & 4.48 & 6.49 & 8.32 & 3.10 & 13.99 & 6.91 \\
\hline
\end{tabular}

$\mathrm{T}_{1}=$ Sole maize (no weeding), $\mathrm{T}_{2}=$ Maize + Mungbean (no weeding), $\mathrm{T}_{3}=$ Maize + Mungbean (weeding at $\left.20 \mathrm{DAE}\right), \mathrm{T}_{4}=$ Maize + Mungbean (weeding at $40 \mathrm{DAE}$ ), $\mathrm{T}_{5}=$ Maize + Mungbean (weeding at 20 and $\left.40 \mathrm{DAE}\right), \mathrm{T}_{6}=$ Maize + Soybean (no weeding), $\mathrm{T}_{7}=$ Maize + Soybean (weeding at $20 \mathrm{DAE}$ ), $\mathrm{T}_{8}=$ Maize + Soybean (weeding at $40 \mathrm{DAE}$ ), $\mathrm{T}_{9}=$ Maize + Soybean (weeding at 20 and $40 \mathrm{DAE}$ ), $\mathrm{T}_{10}=$ Maize + Blackgram (no weeding), $\mathrm{T}_{11}=$ Maize + Blackgram (weeding at 20 DAE), $T_{12}=$ Maize + Blackgram (weeding at $\left.40 \mathrm{DAE}\right), \mathrm{T}_{13}=$ Maize + Blackgram (weeding at 20 and $\left.40 \mathrm{DAE}\right) \mathrm{T}_{14}=$ Sole maize (weed free) , $\mathrm{T}_{15}$ Sole Mungbean (weed free), $\mathrm{T}_{16}=$ Sole Soybean (weed free) and $\mathrm{T}_{17}=$ Sole Blackgram (weed free)

This was probably due to more shading effect of mungbean canopy owing to more number of mungbean plants per unit area (Pandey and Prakash, 2002 and Dwivedi and Shrivastava, 2011). At 20 DAE, the WCE in all the treatments was almost same while at 40 DAE the WCE varied significantly in all treatments. Weed control efficiency of different treatments varied from 14.8-25.3\% at 20 DAE and $17.9-87.53 \%$ at $40 \mathrm{DAE}$, respectively. Among the weed control treatments, two hand weeding at 20 and 40 DAE in maize + mungbean caused the highest weed control efficiency $(24.0-87.5 \%)$ while it was $19.55-85.46 \%$ in maize + soybean and $19.82-80.09 \%$ in maize + blackgram treatments. The reduction in weed population and weed dry biomass in intercropping systems may be attributed to shading effect and competition stress created by canopy of more number of crop plants in a unit area having suppressing effect on associated weeds thus preventing the weeds to attain full growth. Similar results were reported by Pandey and Prakash (2002) that maize and legume intercropped either as paired rows + two rows of legume or one row of legume in between two rows of maize adversely affected the weed growth and caused 22.4 and $31.9 \%$ weed growth suppression as compared to sole maize, respectively. Khan et al. (2011) evaluated the effect of weed control on production potential and economics of maize (Zea mays L.)- legume intercropping system. Among the intercropping systems, $\mathrm{T}_{10}$ (Maize + Blackgram no weeding plot ) gave lower WCE (14.13-22.38\%). 


\section{Yield and yield attributes of maize}

Yield and yield contributing characters were influenced significantly by different intercropping systems and weeding regimes in Kharif season (Table 2). The maximum cob length of maize was found in sole maize $(16.80 \mathrm{~cm})$ and maize + mungbean intercropping $\mathrm{T}_{5}(16.67 \mathrm{~cm})$.

Table 2. Yield attributes of maize in maize + legumes intercropping system during the Kharif season of 2012

\begin{tabular}{ccccc}
\hline Treatments & Cob length (cm) & ${\text { Grains } \text { cob }^{-1} \text { (no.) }}$ & 1000-grain wt. (g) \\
\hline $\mathrm{T}_{1}$ & 16.80 & 486.30 & 273.70 \\
$\mathrm{~T}_{2}$ & 15.53 & 459.00 & 260.50 \\
$\mathrm{~T}_{3}$ & 15.48 & 473.00 & 272.40 \\
$\mathrm{~T}_{4}$ & 15.95 & 484.00 & 268.30 \\
$\mathrm{~T}_{5}$ & 16.67 & 501.00 & 277.50 \\
$\mathrm{~T}_{6}$ & 15.13 & 432.00 & 263.20 \\
$\mathrm{~T}_{7}$ & 15.73 & 440.70 & 269.70 \\
$\mathrm{~T}_{8}$ & 15.97 & 473.00 & 267.90 \\
$\mathrm{~T}_{9}$ & 15.83 & 474.70 & 267.10 \\
$\mathrm{~T}_{10}$ & 15.07 & 436.00 & 264.40 \\
$\mathrm{~T}_{11}$ & 15.50 & 440.00 & 265.80 \\
$\mathrm{~T}_{12}$ & 15.92 & 471.70 & 269.10 \\
$\mathrm{~T}_{13}$ & 15.90 & 478.70 & 272.00 \\
$\mathrm{~T}_{14}$ & 17.70 & 554.00 & 276.90 \\
\hline LSD $_{(0.05)}$ & 1.097 & 38.60 & 5.266 \\
CV (\%) & 4.10 & 4.88 & 1.17 \\
\hline
\end{tabular}

$\mathrm{T}_{1}=$ Sole maize (no weeding), $\mathrm{T}_{2}=$ Maize + Mungbean (no weeding), $\mathrm{T}_{3}=$ Maize + Mungbean (weeding at $\left.20 \mathrm{DAE}\right), \mathrm{T}_{4}=$ Maize + Mungbean (weeding at $40 \mathrm{DAE}), \mathrm{T}_{5}=$ Maize + Mungbean (weeding at 20 and $\left.40 \mathrm{DAE}\right), \mathrm{T}_{6}=\mathrm{Maize}+\mathrm{Soybean}$ (no weeding), $\mathrm{T}_{7}=$ Maize + Soybean (weeding at $\left.20 \mathrm{DAE}\right), \mathrm{T}_{8}=$ Maize + Soybean (weeding at $\left.40 \mathrm{DAE}\right), \mathrm{T}_{9}=\mathrm{Maize}+$ Soybean (weeding at 20 and $40 \mathrm{DAE}$ ), $\mathrm{T}_{10}=$ Maize + Blackgram (no weeding), $\mathrm{T}_{11}=$ Maize + Blackgram (weeding at 20 $\mathrm{DAE}$ ), $\mathrm{T}_{12}=$ Maize + Blackgram (weeding at $\left.40 \mathrm{DAE}\right), \mathrm{T}_{13}=$ Maize + Blackgram (weeding at 20 and $\left.40 \mathrm{DAE}\right)$ and $\mathrm{T}_{14}$ $=$ Sole maize (weed free)

The lowest cob length was obtained from no weeding maize + soybean $\mathrm{T}_{10}(15.07 \mathrm{~cm})$ condition which was statistically at par with $\mathrm{T}_{6}(15.13 \mathrm{~cm})$, treatment. Higher number of grains $\mathrm{cob}^{-1}$ was recorded from weed free sole maize (554) treatment. The lower number of grains $\mathrm{cob}^{-1}$ was observed in no weeding maize + soybean (432) and maize + blackgram (436) intercropping system. Among the intercropping systems, maize + mungbean with two hand weedings $(501)$ gave higher grains $\mathrm{cob}^{-1}$ than all maize + blackgram and maize + soybean intercropping systems. Significant influence was observed in 1000grain weight by the treatments. The highest 1000 -grain weight was recorded from maize + mungbean with two hand weedings intercropping system $(277.5 \mathrm{~g})$ which was statistically at par with weed free sole maize $(276.9 \mathrm{~g})$, no weeding sole maize $(273.7 \mathrm{~g})$, one hand weeding at $20 \mathrm{DAE}$ maize + mungbean intercropping treatment $(272.4 \mathrm{~g})$ and maize + blackgram two hand weedings $(272 \mathrm{~g})$ treatments. Among the intercropping systems, maize + mungbean was obtained higher grains weight than maize + blackgram and maize + soybean association.

Significant influence was observed in yield of maize by the different intercropping situations (Fig. 1). The highest grain yield was obtained from weed free sole maize $\left(8.05 \mathrm{t} \mathrm{ha}^{-1}\right)$ than unweeded sole maize $\left(6.48 \mathrm{t} \mathrm{ha}^{-1}\right)$ treatment. The lowest yield showed in unweeded maize plot in all intercropped situation. Among the intercropping situation, maize + mungbean with two hand weedings $\left(7.18 \mathrm{tha}^{-1}\right)$ treatment marked higher grain yield than maize + blackgram $\left(6.55 \mathrm{t} \mathrm{ha}^{-1}\right)$ and maize + soybean $\left(6.25 \mathrm{t} \mathrm{ha}^{-1}\right)$ 
intercropping systems. Higher yield of maize was observed in monoculture compared to their respective intercropped might be due to no intercrop competition for light, nutrients, moisture and space. This corroborates with the findings of Quayyum and Moniruzzaman (1995) and Uddin et al. (2003). They reported that maize yield was found to be highest from sole crop than intercropped with legume. The reduction of maize yield was probably due to intercrop competition between crops and weeds. Lower crop-weed competition under two hand weedings might have led to better yield components and thus resulted in higher yield (Mundra et al., 2003).

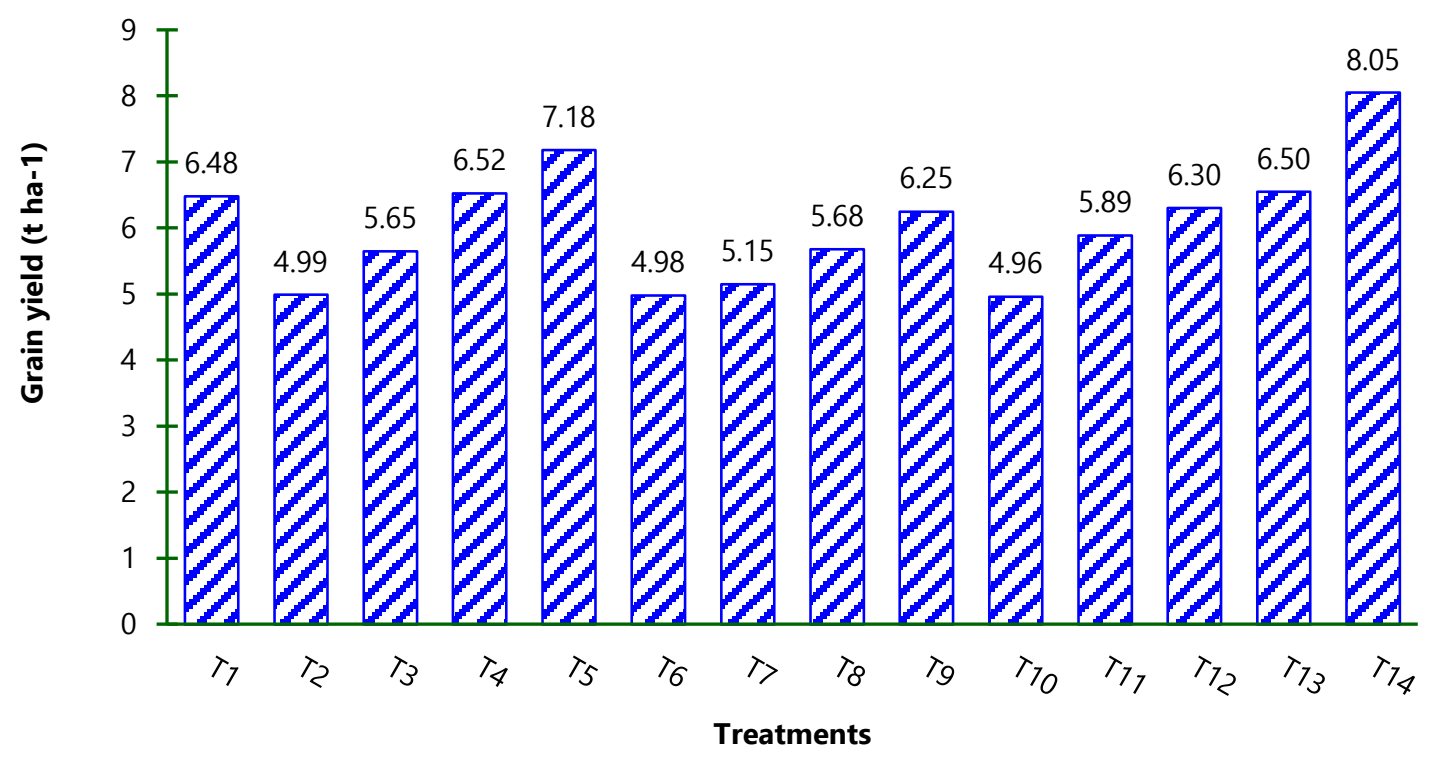

Fig. 1. Grain yield of maize in maize + legumes intercropping system during Kharif season of 2012.

\section{Yield and yield attributes of legumes}

All the yield characters of legumes were significantly influenced by the treatments of maize + legumes intercropping systems (Table 3). Higher number of pods plant $^{-1}$ was recorded in intercropped soybean (80) which was statistically similar with sole soybean (78) and the lowest one was in intercropped mungbean (16.43) that was similar with others mungbean treatments. Among the legumes intercropping systems, maize + soybean was found in higher number of pods plant ${ }^{-1}$ with varying weeding regime (Akhteruzzaman and Quayyum, 1991) who reported that number of pods plant ${ }^{-1}$ of $^{2}$ legumes were reduced by intercropping in Kharif season. The highest seeds pod $^{-1}$ was obtained in sole legumes, except mungbean. Among the intercropping systems, maize + mungbean intercropping gave higher number of seeds pod $^{-1}$ than other maize + soybean and maize + blackgram intercropping (Table 3). Maximum 1000-seed weight was observed in soybean mono cropping system which was followed by soybean with two hand weedings in intercropping treatments. The lowest 1000 -seed weight was observed in blackgram intercropping treatments. 
Table 3. Yield attributes of legumes in maize + legumes intercropping system during the Kharif season of 2012

\begin{tabular}{cccc}
\hline Treatments & $\begin{array}{c}\text { Pods plant }^{-1} \\
\text { (no.) }\end{array}$ & $\begin{array}{c}\text { Seeds pod } \\
\text { (no. }^{-1}\end{array}$ & $\begin{array}{c}\text { 1000-seed weight } \\
\text { (g) }\end{array}$ \\
\hline $\mathrm{T}_{2}$ & $16.57 \mathrm{f}$ & $12.17 \mathrm{a}$ & $36.30 \mathrm{de}$ \\
$\mathrm{T}_{3}$ & $16.43 \mathrm{f}$ & $13.33 \mathrm{a}$ & $37.13 \mathrm{c}-\mathrm{e}$ \\
$\mathrm{T}_{4}$ & $16.77 \mathrm{f}$ & $13.13 \mathrm{a}$ & $38.40 \mathrm{c}-\mathrm{e}$ \\
$\mathrm{T}_{5}$ & $18.83 \mathrm{f}$ & $13.53 \mathrm{a}$ & $39.63 \mathrm{~b}-\mathrm{e}$ \\
$\mathrm{T}_{6}$ & $52.67 \mathrm{c}$ & $2.46 \mathrm{c}$ & $31.33 \mathrm{f}$ \\
$\mathrm{T}_{7}$ & $70.67 \mathrm{~b}$ & $2.433 \mathrm{c}$ & $41.00 \mathrm{bc}$ \\
$\mathrm{T}_{8}$ & $70.33 \mathrm{~b}$ & $2.467 \mathrm{c}$ & $37.33 \mathrm{c}-\mathrm{e}$ \\
$\mathrm{T}_{9}$ & $79.67 \mathrm{a}$ & $2.500 \mathrm{c}$ & $43.33 \mathrm{ab}$ \\
$\mathrm{T}_{10}$ & $26.00 \mathrm{e}$ & $5.667 \mathrm{~b}$ & $35.17 \mathrm{ef}$ \\
$\mathrm{T}_{11}$ & $37.67 \mathrm{~d}$ & $5.667 \mathrm{~b}$ & $35.27 \mathrm{ef}$ \\
$\mathrm{T}_{12}$ & $35.43 \mathrm{~d}$ & $6.000 \mathrm{~b}$ & $36.07 \mathrm{de}$ \\
$\mathrm{T}_{13}$ & $38.57 \mathrm{~d}$ & $6.333 \mathrm{~b}$ & $36.63 \mathrm{c}-\mathrm{e}$ \\
$\mathrm{T}_{15}$ & $18.83 \mathrm{f}$ & $12.33 \mathrm{a}$ & $40.57 \mathrm{~b}-\mathrm{d}$ \\
$\mathrm{T}_{16}$ & $78.33 \mathrm{a}$ & $2.933 \mathrm{c}$ & $46.00 \mathrm{a}$ \\
$\mathrm{T}_{17}$ & $47.67 \mathrm{c}$ & $6.667 \mathrm{~b}$ & $39.27 \mathrm{~b}-\mathrm{e}$ \\
\hline $\mathrm{LSD}_{(0.05)}$ & 6.244 & 1.257 & 3.936 \\
$\mathrm{CV}_{(\%)}$ & 8.97 & 10.47 & 6.16 \\
\hline
\end{tabular}

$\mathrm{T}_{1}=$ Sole maize (no weeding), $\mathrm{T}_{2}=$ Maize + Mungbean (no weeding), $\mathrm{T}_{3}=$ Maize + Mungbean (weeding at $\left.20 \mathrm{DAE}\right), \mathrm{T}_{4}=$ Maize + Mungbean (weeding at $40 \mathrm{DAE}$ ), $\mathrm{T}_{5}=$ Maize + Mungbean (weeding at 20 and $\left.40 \mathrm{DAE}\right), \mathrm{T}_{6}=$ Maize + Soybean (no weeding), $\mathrm{T}_{7}=$ Maize + Soybean (weeding at $20 \mathrm{DAE}$ ), $\mathrm{T}_{8}=$ Maize + Soybean (weeding at $40 \mathrm{DAE}$ ), $\mathrm{T}_{9}=$ Maize + Soybean (weeding at 20 and $40 \mathrm{DAE}$ ), $\mathrm{T}_{10}=$ Maize + Blackgram (no weeding), $\mathrm{T}_{11}=$ Maize + Blackgram (weeding at 20 DAE), $T_{12}=$ Maize + Blackgram (weeding at $\left.40 \mathrm{DAE}\right), \mathrm{T}_{13}=$ Maize + Blackgram (weeding at 20 and $\left.40 \mathrm{DAE}\right) \mathrm{T}_{14}=$ Sole maize (weed free), $T_{15}=$ Sole Mungbean (weed free), $T_{16}=$ Sole Soybean (weed free) and $T_{17}=$ Sole Blackgram (weed free)

Seed yield of legumes was influenced by the treatments (Fig. 2). Sole legumes produced the highest seed yield then it reduced significantly when it was grown in association with maize as intercrop. The higher seed yield produced from maize + mungbean intercropping with two hand weedings $(572.6 \mathrm{~kg}$ $\left.\mathrm{ha}^{-1}\right)$ which was followed by maize + blackgram $\left(510.8 \mathrm{~kg} \mathrm{ha}^{-1}\right)$ and maize + soybean $\left(502.9 \mathrm{~kg} \mathrm{ha}^{-1}\right)$ intercropping systems. The lowest yield was obtained by mungbean no weeding treatment $(302.4 \mathrm{~kg} \mathrm{ha}$ ${ }^{1}$ ) which was statistically similar with maize + blackgram no weeding $\left(316.6 \mathrm{~kg} \mathrm{ha}^{-1}\right)$ and maize + soybean no weeding $\left(333.7 \mathrm{~kg} \mathrm{ha}^{-1}\right)$ treatments. Reduced yield of legumes under different intercropping situations was due to less population (67\%) compared with sole crop of legumes (100\%). Besides, legumes yield was poor due to less availability of light and nutrient in intercropping situation and also shading effect of maize. These findings were in accordance to those of Torofder et al. (1992) and Razzaque et al. (2007). Among the intercropped treatments, weeding done twice at 20 and $40 \mathrm{DAE}$ resulted higher grain yield of mungbean than one hand weeding and no weeding treatment due to better growth environment. They also reported that, weeding done at 45 days appeared to have an adverse effect on crop yield as it might have distributed the root zone of the plants. A delay in weeding resulted in reduction of crop yield. It also might be due two hand weedings intercropping systems favoured of intercropped mungbean and judicious use of growth resources compared to other intercropped combinations. 


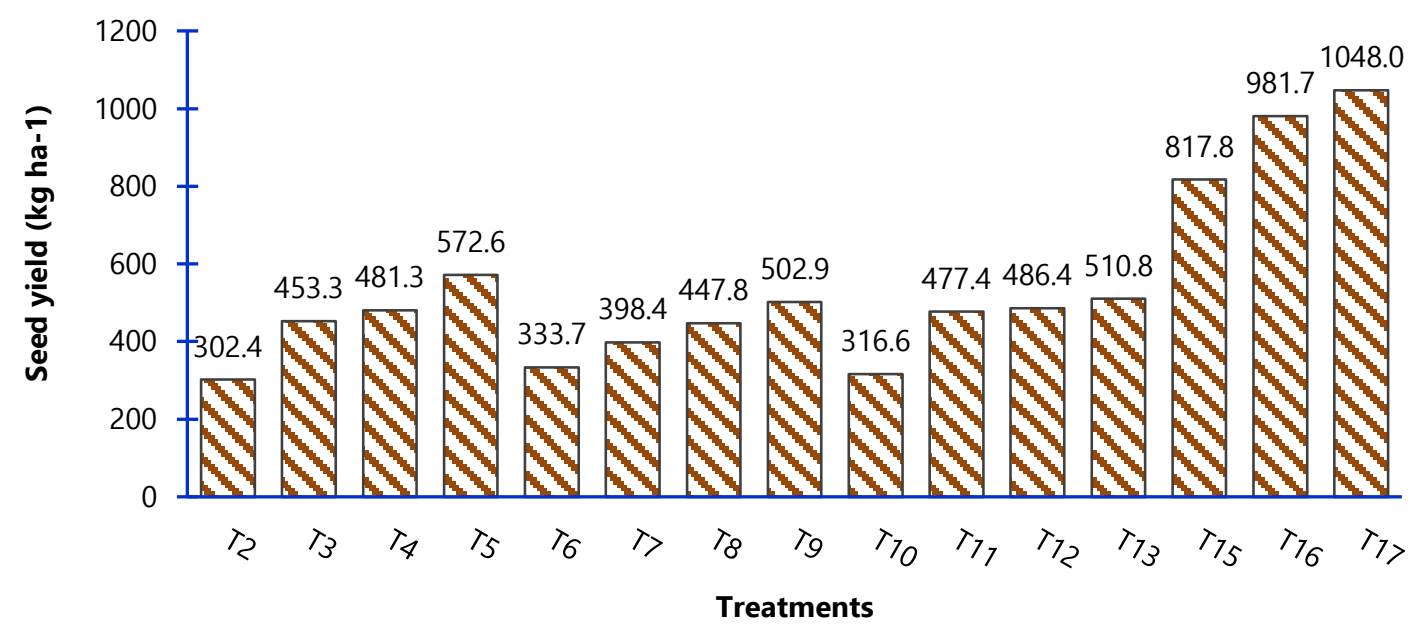

Fig. 2. Seed yield of legumes in maize + legumes intercropping system during the Kharif season of 2012.

\section{Assessment of competition and evaluation of intercrop productivity}

Competitive ratio index was used to assess the competition effects of maize and component crops in the maize + legume intercropping system. Competitive ratio values showed the variability in competitive ability of component crops with the variation of intercropping systems. Results showed that all treatments of maize intercropping had higher competitive ability of maize than legumes (Table 4).Among thethree intercropping systems, maize + soybean and maize + blackgram intercropping association performed better than maize + mungbean intercropping systems.

Table 4. Competitive ratio of maize and legumes in intercropping systems during the Kharif season of 2012

\begin{tabular}{cccc}
\hline Treatments & \multicolumn{3}{c}{ Competitive ratio } \\
\cline { 2 - 4 } & Maize & Legumes & Difference \\
\hline $\mathrm{T}_{2}$ & 1.39 & Mungbean & 0.67 \\
$\mathrm{~T}_{3}$ & 1.02 & 0.72 & 0.08 \\
$\mathrm{~T}_{4}$ & 1.14 & 0.94 & 0.26 \\
$\mathrm{~T}_{5}$ & 1.06 & 0.88 & 0.12 \\
& & 0.94 & \\
$\mathrm{~T}_{6}$ & 1.51 & Soybean & 0.85 \\
$\mathrm{~T}_{7}$ & 1.31 & 0.66 & 0.55 \\
$\mathrm{~T}_{8}$ & 1.28 & 0.76 & 0.50 \\
$\mathrm{~T}_{9}$ & 1.27 & 0.78 & 0.49 \\
& & 0.78 & \\
$\mathrm{~T}_{10}$ & 1.61 & Blackgram & 0.99 \\
$\mathrm{~T}_{11}$ & 1.27 & 0.62 & 0.48 \\
$\mathrm{~T}_{12}$ & 1.33 & 0.79 & 0.58 \\
$\mathrm{~T}_{13}$ & 1.29 & 0.75 & 0.51 \\
\hline
\end{tabular}

$\mathrm{T}_{1}=$ Sole maize (no weeding), $\mathrm{T}_{2}=$ Maize + Mungbean (no weeding), $\mathrm{T}_{3}=$ Maize + Mungbean (weeding at $\left.20 \mathrm{DAE}\right), \mathrm{T}_{4}=$ Maize + Mungbean (weeding at $40 \mathrm{DAE}), \mathrm{T}_{5}=$ Maize + Mungbean (weeding at 20 and $\left.40 \mathrm{DAE}\right), \mathrm{T}_{6}=\mathrm{Maize}+\mathrm{Soybean}$ (no weeding), $\mathrm{T}_{7}=$ Maize + Soybean (weeding at $\left.20 \mathrm{DAE}\right), \mathrm{T}_{8}=$ Maize + Soybean (weeding at $\left.40 \mathrm{DAE}\right), \mathrm{T}_{9}=\mathrm{Maize}+$ Soybean (weeding at 20 and $40 \mathrm{DAE}$ ), $\mathrm{T}_{10}=$ Maize + Blackgram (no weeding), $\mathrm{T}_{11}=$ Maize + Blackgram (weeding at 20 DAE), $T_{12}=$ Maize + Blackgram (weeding at 40 DAE), $T_{13}=$ Maize + Blackgram (weeding at 20 and 40 DAE) 


\section{Evaluation of intercrop productivity}

Intercrop productivity was evaluated by equivalent yield, land equivalent ratio and monetary advantage (Table 5). The maximum maize equivalent yield $\left(10.62 \mathrm{t} \mathrm{ha}^{-1}\right)$ was obtained from $\mathrm{T}_{5}$ treatment. The results showed that all the intercropping systems gave higher maize equivalent yield than that of their corresponding sole crop yield. The lowest maize equivalent yield $\left(6.48 \mathrm{t} \mathrm{ha}^{-1}\right)$ was obtained from no weeding regime of sole maize. Akhteruzzaman and Quayyum (1991) and Patra et al. (2000) also reported similar observations in different intercropping systems.

Land equivalent ratio varied from 1.07 to 1.81 in intercropping systems with different hand weeding treatments (Table 6). The highest land equivalent ratio (LER) was 1.81 in maize + mungbean with two hand weedings situation and the lowest (1.07) was in maize + blackgram intercropping with no weeding situation. The results showed that the total gross return was higher in all the intercropping systems compared to their respective sole crop. Higher total gross return of Tk. 108853 ha $^{-1}$ was obtained from maize + mungbean intercropping with two hand weedings situation. On the other hand, the lowest gross return of Tk. $50643 \mathrm{ha}^{-1}$ from sole situation in mungbean treatment (Table 6). The cost of cultivation increased in the intercropping systems compared with the respective sole crop of maize and legumes. It might be due to increased seed requirement and additional cultural practices for legumes in the intercropping systems. The results support those of Patel and Rajagopal (2001) under cereal + legume intercropping system. The highest cost of cultivation was observed in maize + soybean (Tk. $45035 \mathrm{ha}^{-1}$ ) intercropping systems. The lowest cost of cultivation was Tk. $30515 \mathrm{ha}^{-1}$ from sole situation of mungbean. The cost of cultivation increased in the intercropping system over the respective sole crops of legumes due to another crop addition in this system.

Table 5. Equivalent yield and land equivalent ratio of maize + legume intercropping systems at different weeding regime during the Kharif season of 2012

\begin{tabular}{ccc}
\hline Treatments & Maize equivalent yield $\left(\mathbf{t ~ h a}^{\mathbf{1}}\right)$ & Land equivalent ratio \\
\hline $\mathrm{T}_{1}$ & 6.48 & 1.00 \\
$\mathrm{~T}_{2}$ & 6.80 & 1.14 \\
$\mathrm{~T}_{3}$ & 8.37 & 1.42 \\
$\mathrm{~T}_{4}$ & 8.41 & 1.60 \\
$\mathrm{~T}_{5}$ & 10.62 & 1.81 \\
$\mathrm{~T}_{6}$ & 6.98 & 1.11 \\
$\mathrm{~T}_{7}$ & 7.54 & 1.20 \\
$\mathrm{~T}_{8}$ & 8.37 & 1.34 \\
$\mathrm{~T}_{9}$ & 9.27 & 1.48 \\
$\mathrm{~T}_{10}$ & 6.86 & 1.07 \\
$\mathrm{~T}_{11}$ & 8.75 & 1.34 \\
$\mathrm{~T}_{12}$ & 9.22 & 1.43 \\
$\mathrm{~T}_{13}$ & 8.62 & 1.51 \\
$\mathrm{~T}_{14}$ & 8.05 & 1.00 \\
$\mathrm{~T}_{15}$ & - & 1.00 \\
$\mathrm{~T}_{16}$ & - & 1.00 \\
$\mathrm{~T}_{17}$ & - & 1.00 \\
\hline
\end{tabular}

$\mathrm{T}_{1}=$ Sole maize (no weeding), $\mathrm{T}_{2}=$ Maize + Mungbean (no weeding), $\mathrm{T}_{3}=$ Maize + Mungbean (weeding at $\left.20 \mathrm{DAE}\right), \mathrm{T}_{4}=$ Maize + Mungbean (weeding at $40 \mathrm{DAE}$ ), $\mathrm{T}_{5}=$ Maize + Mungbean (weeding at 20 and $40 \mathrm{DAE}$ ), $\mathrm{T}_{6}=\mathrm{Maize}+\mathrm{Soybean}$ (no weeding), $\mathrm{T}_{7}=$ Maize + Soybean (weeding at $\left.20 \mathrm{DAE}\right), \mathrm{T}_{8}=$ Maize + Soybean (weeding at $\left.40 \mathrm{DAE}\right), \mathrm{T}_{9}=\mathrm{Maize}+$ Soybean (weeding at 20 and $40 \mathrm{DAE}$ ), $\mathrm{T}_{10}=$ Maize + Blackgram (no weeding), $\mathrm{T}_{11}=$ Maize + Blackgram (weeding at 20 $\mathrm{DAE}), \mathrm{T}_{12}=$ Maize + Blackgram (weeding at $\left.40 \mathrm{DAE}\right), \mathrm{T}_{13}=$ Maize + Blackgram (weeding at 20 and $\left.40 \mathrm{DAE}\right) \mathrm{T}_{14}=\mathrm{Sole}$ maize (weed free) , $\mathrm{T}_{15}$ Sole Mungbean (weed free), $\mathrm{T}_{16}=$ Sole Soybean (weed free) and $\mathrm{T}_{17}=$ Sole Blackgram (weed free) 
Table 6. Cost benefit analysis of different maize + legume intercropping systems during the Kharif season of 2012

\begin{tabular}{|c|c|c|c|c|c|c|}
\hline \multirow[t]{2}{*}{ Treatments } & \multicolumn{3}{|c|}{ Gross return $\left(\mathrm{Tk} . \mathrm{ha}^{-1}\right)$} & \multirow{2}{*}{$\begin{array}{l}\text { Cost of cultivation } \\
\left(\mathrm{Tk} . \mathrm{ha}^{-1}\right)\end{array}$} & \multirow{2}{*}{$\begin{array}{l}\text { Net return } \\
\left(T k . h^{-1}\right)\end{array}$} & \multirow[t]{2}{*}{$\overline{\text { BCR }}$} \\
\hline & Maize & Legume & Total & & & \\
\hline $\mathrm{T}_{1}$ & 66388 & - & 66388 & 40515 & 25873 & 1.64 \\
\hline $\mathrm{T}_{2}$ & 51472 & 19161 & 70633 & 41715 & 28918 & 1.69 \\
\hline $\mathrm{T}_{3}$ & 58067 & 28298 & 86365 & 43215 & 43150 & 2.00 \\
\hline $\mathrm{T}_{4}$ & 66755 & 29918 & 96673 & 43215 & 53458 & 2.24 \\
\hline $\mathrm{T}_{5}$ & 73430 & 35423 & 108853 & 44000 & 64853 & 2.47 \\
\hline $\mathrm{T}_{6}$ & 51325 & 22791 & 74115 & 40034 & 34081 & 1.85 \\
\hline $\mathrm{T}_{7}$ & 52953 & 27121 & 80074 & 42535 & 37539 & 1.88 \\
\hline $\mathrm{T}_{8}$ & 58295 & 30415 & 88710 & 42535 & 46175 & 2.09 \\
\hline $\mathrm{T}_{9}$ & 64042 & 34081 & 98123 & 45035 & 53088 & 2.18 \\
\hline $\mathrm{T}_{10}$ & 51005 & 19921 & 70926 & 41115 & 29811 & 1.73 \\
\hline $\mathrm{T}_{11}$ & 60475 & 29611 & 90086 & 42615 & 47471 & 2.11 \\
\hline $\mathrm{T}_{12}$ & 64613 & 30176 & 94789 & 42615 & 52174 & 2.22 \\
\hline $\mathrm{T}_{13}$ & 67092 & 31698 & 98790 & 43015 & 55775 & 2.30 \\
\hline $\mathrm{T}_{14}$ & 82308 & - & 82308 & 44675 & 37633 & 1.84 \\
\hline $\mathrm{T}_{15}$ & - & 50643 & 50643 & 30515 & 20128 & 1.66 \\
\hline $\mathrm{T}_{16}$ & - & 65669 & 65669 & 32785 & 32884 & 2.00 \\
\hline $\mathrm{T}_{17}$ & - & 64322 & 64322 & 30555 & 33767 & 2.11 \\
\hline
\end{tabular}

$\mathrm{T}_{1}=$ Sole maize (no weeding), $\mathrm{T}_{2}=$ Maize + Mungbean (no weeding), $\mathrm{T}_{3}=$ Maize + Mungbean (weeding at $\left.20 \mathrm{DAE}\right), \mathrm{T}_{4}=$ Maize + Mungbean (weeding at $40 \mathrm{DAE}$ ), $\mathrm{T}_{5}=$ Maize + Mungbean (weeding at 20 and $40 \mathrm{DAE}$ ), $\mathrm{T}_{6}=$ Maize + Soybean (no weeding), $\mathrm{T}_{7}=$ Maize + Soybean (weeding at $20 \mathrm{DAE}$ ), $\mathrm{T}_{8}=$ Maize + Soybean (weeding at $\left.40 \mathrm{DAE}\right), \mathrm{T}_{9}=$ Maize + Soybean (weeding at 20 and $40 \mathrm{DAE}$ ), $\mathrm{T}_{10}=$ Maize + Blackgram (no weeding), $\mathrm{T}_{11}=$ Maize + Blackgram (weeding at 20 DAE), $T_{12}=$ Maize + Blackgram (weeding at $\left.40 \mathrm{DAE}\right), \mathrm{T}_{13}=$ Maize + Blackgram (weeding at 20 and $\left.40 \mathrm{DAE}\right) \mathrm{T}_{14}=$ Sole maize (weed free), $T_{15}$ Sole Mungbean (weed free) , $T_{16}=$ Sole Soybean (weed free) and $\mathrm{T}_{17}=$ Sole Blackgram (weed free)

Market price: Mungbean Tk. $30 \mathrm{~kg}^{-1}$; Blackgram Tk. $15 \mathrm{~kg}^{-1}$; Soybean Tk. $15 \mathrm{~kg}^{-1}$ and Maize Tk. $12 \mathrm{~kg}^{-1}$.

The higher BCR (benefit cost ratio) was observed from same treatment of the maize + mungbean with two hand weedings situation (2.47) but sole legumes gave also higher BCR than other situations except mungbean (1.66). Sole maize with no weeding treatment gave lower BCR than other intercropping systems (1.64).

\section{Conclusion}

The results of this study revealed that intercropping of two rows of mungbean in between two rows of maize with two hand weeding at 20 and $40 \mathrm{DAE}$ to be a profitable practice for good yield advantages, optimum exploitation of the environmental resources, weed control efficiencies, LER and monetary values.

\section{References}

Akhteruzzaman, M. and M.A. Quayyum. 1991. Intercropping of maize with three varieties of groundnut at two levels of plant population. Bangladesh J. Agril. Sci. 18(1): 39-44.

Banddyopadhyay, S.N. 1984. Nitrogen and water relations in grain sorghum legume intercropping systems. Ph. D. Dissertation, Indian Agril. Res. Insti. New Delhi. 
Baumann D.T., M.J. Kropf and L. Bastiaans. 2000. Intercropping leeks to suppress weeds. Weed Res. 40: 361-376.

Cruz, F.D., K. Moody and M.B.D. Ramas. 1986. Reducing variability sampling weeds in upland rice (Oryza sativa). Philopp J. Weed Sci. 13: 56-59.

Dwivedi, S.K. and G.K. Shrivastava. 2011. Planting geometry and weed management for maize (Zea mays) - blackgram (Vigna mungo) intercropping system under rainfed vertisols. Indian J. Agron. 56(3): 202-208.

Getachew, A., G. Amare and W. Sinebo. 2007. Cereal-faba bean mixed cropping: Yield advantage and land use ei ciency. Res. Rep. 70. Ethopian Inst. Agric. Res., Addis Ababa, Ethiopia.

Katsaruware, R.D. and I.O. Manyanhaire. 2009. Maize-cowpea intercropping and weed suppression in leaf stripped and detasselled maize in Zimbabwe. J. Environ. Agric. Food Chemis. 8(1): 1218-1226.

Khan, M.A., A.N. Khan, R. Khan, Umm-e-Kalsoom and M.A. Khan. 2011. Weed control efficiency of intercropping legumes in maize. Pak. J. Weed Sci. Res. 17(4): 303-312.

Kumar, A. and K.S. Thakur. 2005. Influence of intercropping and weed control measures on weeds and productivity of rainfed maize (Zea mays). Ind. J. Weed Sci. 37: 65-67.

Mundra, S.L., A.K. Vyas and P.L. Maliwal. 2003. Effect of weed and nutrient management on weed growth and productivity of maize (Zea mays L.). Indian J. Weed Sci. 35(1\&2): 57-61.

Odedina, J.N, T.O, Fabunmi, S.O. Adigbo, S.A. Odedina and R.O. Kolawole. 2014. Evaluation of cowpea varieties (Vigna unguiculata L. Walp) for intercropping with okra (Abelmoschus esculenta, L Moench). J. Res. Com. 2(2): 91-108.

Pandey, A.K. and V. Prakash. 2002. Weed management in maize and soybean intercropping system. Indian J. Weed Sci. 34(1\&2): 58-62.

Patel, J.R. and Rajagopal, S. 2001. Production potential of forage maize (Zea mays L.) with legumes under intercropping systems. Indian J. Agron. 46(2): 211-215.

Patel, V.J., P.N. Upadhyay, J.B. Patel and M.I. Meisuriya. 2006. Effect of herbicide mixture on weeds in kharif maize (Zea mays L.) under middle Gujarat conditions. Indian J. Weed Sci. 38(1\&2): 54-57.

Patra, B.C., B.K. Mandal and A.L. Padhi. 2000. Production potential of winter maize (Zea mays L.) based intercropping systems. Indian J. Agril. Sci. 70(4): 203-206.

Quayyum, M.A. and A.F.M. Maniruzzaman. 1995. Effect of maize (Zea mays L.) and rice (Oryza sativa) with blackgram (Phaseolus mungo). Indian J. Agron. 40(1): 20-25.

Razzaque, M.A., S. Rafiquzzaman, M.M. Bazzaz, M.A. Ali and M.M.R. Talukdar. 2007. Study on the intercropping groundnut with chill at different plant populations. Bangladesh J. Agril. Res. 32(1): $37-43$.

Seran, T.H. and I. Brintha. 2010. Review on maize based intercropping. J. Agron. 9(3): 135-145.

Torofder, G.S., A. Ahmed, M.M. Alam and M.A. Quayyum. 1992. Intercropping of maize with different legume. Bangladesh J. Life Sci. 4(2): 33-37.

Uddin, M.S., M.J. Rahman, S.A. Begum and M.R. Ali. 2003. Intercropping of maize with soybean in saline area under rainfed condition. Bangladesh J. Agril. Res. 28(3): 451-455.

Undie, U.L., D.F. Uwah and E.E. Attoe. 2012. Effect of intercropping and crop arrangement on yield and productivity of late season Maize/soybean mixtures in the humid environment of South Southern Nigeria. J. Agril. Sci. 4(4): 37-50.

Willey, R.W. 1979. Intercropping: Its importance and research needs. Field Crops Abs. 32(1): 1-10.

Willey, R.W. and M.R. Rao. 1980. A competitive ratio for quantifying competition between intercrops. Expl. Agric. 16: 117-125.

Wortmann, C.S., M. Mamo, C. Mburu, E. Letayo, G. Abebe, K.C. Kayuki, M. Chisi, M. Mativavarira, S. Xerinda, and T. Ndacyayisenga. 2009. Atlas of sorghum (Sorghum bicolor (L.) Moench) production in eastern and south-ern Africa. Univ. of Nebraska-Lincoln, Lincoln. 